\title{
The agricultural potentialities of the Transvaal
}

\section{William Macdonald M.S.Agr., Ph.D., Editor}

To cite this article: William Macdonald M.S.Agr., Ph.D., Editor (1909) The agricultural potentialities of the Transvaal, Scottish Geographical Magazine, 25:1, 12-18, DOI: $10.1080 / 00369220908733930$

To link to this article: http://dx.doi.org/10.1080/00369220908733930

曲 Published online: 27 Feb 2008.

Submit your article to this journal $₫$

山 Article views: 4

Q View related articles ¿ 


\title{
THE AGRICULTURAL POTENTIALITIES OF THE TRANSVAAL.
}

\author{
By William Macdonadd, M.S.Agr., Ph.D., Editor, Transvaal \\ Department of Agriculture.
}

Most people are aware-as Herr Dernburg, the German Colonial Secretary, pointed out during his recent visit to Johannesburg-that the Transvaal produces a third part of the world's gold output, but few, perhaps, realise the far vaster potentialities of the agricultural industry. I propose, therefore, to show by means of a few figures what the farmer in the near future may produce in farm crops, fruit, and live stock.

Let us start with our staple crop-maize, or the humble mealie. It is a well-known fact that maize can be grown on every farm in the Transvaal, and, what is most important, it is essentially a dry-land crop. The present yield is, roughly, four bags to the acre. This low figure is mainly due to the careless preparation of the fields in the first instance, and, secondly, to the lack of after-cultivation. It is most disheartening to see so many maize-fields in this colony full of hard lumps, grass, and choked with weeds, which soon become radiating centres of noxious seeds. Deep ploughing, harrowing, and constant cultivation-so as to preserve the surface mulch or dust blanket, and so retain the soil moisture-are the main factors for successful maize-growing. With these simple methods-all of which, however, mean much labour for the grower-the yield of maize might readily be doubled, and the crop rendered much less precarious.

Let us take a simple sum to show what the mealie farmer of the future might harvest. Suppose it were possible to place one-tenth part of the Transvaal under maize, see what this would mean :-One-tenth of the Transvaal $=7,100,000$ acres at 4 bags per acre $=28,400,000$ bags. $^{1}$ But, if by good cultivation we were able to raise this figure to 8 bags, it would be $56,800,000$ bags, or a difference of, say, $£ 14,200,000$, viz. half the value of our gold production for one year.

Let us now take wheat. The imports of wheat and wheat products into the Transvaal for the year ending 31st December 1907 were $£ 527,480$. The question naturally arises: "Could not this be produced here, and so save such a large sum of money from going out of the country?" Owing to the prevalence of rust during the summer season, wheat-growing in the Trausvaal is mostly restricted to the winter months-from May until October. This being the dry season, the wheat is grown mainly as an irrigated crop.

It is probable, however, that by means of dry-land farming methods a large acreage could be put under wheat, and so much land now going waste during the winter months might be profitably used. Let the farmer select a good rich loam, plough deeply and harrow well during 
the rainy season in summer, and harrow well after every rain until the time of planting in April and May, thus conserving the rainfall in the soil reservoir by means of a loose soil mulch; and it is more than likely that the corn will germinate, grow, and ripen with the natural rainfall, and before the rust fungus has attacked the plant.

It is difficult, in the absence of any reliable data, to give the exact yield of wheat per acre or morgen. Mr. Burtt-Davy, the Government botanist, measured two actual cases and found the yield of wheat grown under irrigation to be 29 bushels (of $63 \mathrm{lbs}$.), or 9 sacks of $203 \mathrm{lbs}$. Now, how does that compare with other countries? Well, in the case of the State of Minnesota the average yield is only 13 bushels per acre, but in England, with superior methods of cultivation, the average yield is 31 .

It is surprising that almost every farmer who grows wheat raises a still larger area of oat-forage, also under irrigation. If the growing of green forage on good wheat lands were abandoned, the production of wheat might easily be doubled. Let us take a case in point. Suppose, for example, that we could put the whole of Marico, a small district, under wheat as representing the total available wheat-growing area of this colony, then we have 2,820,640 acres; and if we take 20 bushels to the acre as the average production for wet and dry lands, we get the following total-46,412,800 bushels. Or, in other words, one-sixth part of the 262,700,000 bushels of wheat annually absorbed by Great Britain, and worth over $£ 7,000,000$.

Turn now to tobacco. It is well known that certain portions of the Transvaal are specially suited to the production of superior tobacco. But two things remain to be done. In the first place, it will be necessary to reduce largely the cost of production per acre, and, secondly, to improve the quality. It is regrettable that at the present time an enormous amount of inferior tobacco is annually found upon our local markets. This is mainly due to the fact that a large percentage of farmers have taken up tobacco-growing without having had any previous training in this branch of agriculture. It is extraordinary that Transvaal tobacco has gained such a widespread reputation in spite of the very primitive methods of cultivation and the utter lack of care regarding the details of curing.

Furthermore, we must try to create an export trade for bright tobaccos-cigarettes, etc.-and cigar leaf. The former can be raised economically on certain soils in the districts of Rustenburg, Pretoria, and Waterberg; and the latter in different parts of the Zoutpansberg, Lydenburg, and Barberton, where a moister climate prevails. In the meantime, however, there is a good demand for both those types of tobacco in the various colonies of South Africa, and at prices higher than can be obtained in the world's markets. Space does not permit me to speak at length of the recent growth of this industry. Suffice it

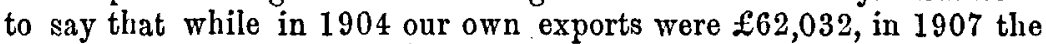

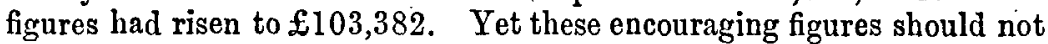
let us rest upon our oars when we remember that the State of Kentucky, with an area of 40,400 square miles-or a little more than one-third the 
size of the Transvaal-produced, during the same year, 240,478,000 pounds of tobacco, valued at $£ 4,905,800$ approximately.

Recently, we have heard much in regard to the cotton industry of America, and the question naturally arises: "What are our prospects in the Transvaal?" Various experiments conducted by the Department of Agriculture in different parts of this colony have shown that the whole of the Low Veld, and many parts of the Middle Veld, are admirably adapted to the cultivation of cotton. But the most suitable areas have been found to be the eastern foothills of the Drakensberg, the Zoutpansberg, Lydenburg, Barberton, and the Piet Retief Districts, together with Swaziland. So far as varieties are concerned, the best results have been obtained with the improved type of American Upland Cotton, excellent specimens of which have been grown in the Zoutpansberg and Waterberg districts, being valued at $\frac{1}{2} \mathrm{~d}$. to $1 \frac{1}{2} \mathrm{~d}$. per $\mathrm{lb}$. in advance of the best "middling" American cotton. It is well known that America possesses the greatest cotton-fields in the world, and her largest State, Texas, with the vast area of 265,780 square miles of territory, or much more than twice the size of the whole Transvaal, produced the splendid crop of $4,281,824$ bales $^{1}$ in 1906 . Yet how many people realise that were we able to place an area under cotton, in size a little more than one-third of the district of Zoutpansberg, we should surpass this magnificent figure.

Next, a word regarding the greatest fodder crop of the day-lucerne. This crop has been grown for many years in the Old World, but so far as I am aware the only lucerne in the Transvaal before the war consisted of a fow garden-patches near Pretoria and Potchefstroom, and one or two other plots of not more than a quarter of an acre in extent. Within the past six years some hundreds of acres have been laid under lucerne, and it is now being rapidly extended both on irrigable and dry lands. The average annual yield of lucerne hay on irrigated lands may be taken at six tons per acre, and placing this at $£ 5$ per ton a yearly income of $£ 30$ per annum may be expected, besides a considerable amount of valuable grazing. There are to-day some 12,000 farms in the Transvaal, having an average of 5000 acres each. Let us suppose that 20 acres on each farm could be laid down to lucerne under water either by means of a furrow or a windmill, and we get a total of 240,000 acres, which at 6 tons per annum $=1,440,000$ tons, of a value of

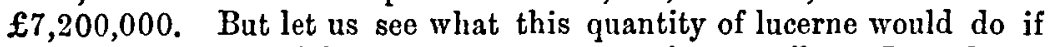
we had the same weight, viz. 1,440,000 tons, in our silos. I need not weary the reader with the details of these figures, but will simply state that this amount of lucerne would feed 800,000 head of cattle for a period of three months at a daily ration of $40 \mathrm{lbs}$. for each animal.

Consider now the potentialities of our fruit industry. It is well known that the Transvaal is peculiarly adapted to a large variety of temperate, semi-tropical, and tropical fruits. The following fruits thrive in different districts : apples, pears, plums, peaches, apricots, nectarines, cherries, quinces, walnuts, prunes, persimmons, olives, grapes, almonds, 
figs, loquats, oranges, lemons, citrons, mangoes, litchis, bayanas, avocadopears, pineapples, and paw-paws. It would be easy to write several pages on the possibilities of each one of those fruits : but our space does not permit. The other day we were gratified to hear that one million and a half of oranges would be exported this season from the district of Rustenburg. At first sight this seems a large figure, but we know it is only a very small beginning.

Let us take that curbing ribbon of land which runs from Pretoria to a point thirty miles beyond Rustenburg, lying in the base of the northern slope of the Magaliesberg Mountains - an area 100 miles long by 4 miles broad-and we get an area of 400 square miles, or 256,000 acres, of rich red loam bearing a striking resemblance to the celebrated orange soils of Southern California. Plant this area-only a very small portion of the possible citrus lands of the Transvaal-and at 75 trees per acre you will set out $19,200,000$ trees of an annual bearing value of $\mathfrak{£} 9,600,000$.

It would take far too long to touch upon the vast wealth which will yet be won by energetic growers of such crops as sugar cane and sugar beet, coffee and tea, sisal hemp and flax, castor-oil and ground nuts, tan and dye plants, velvet beans and cassava. But we may recall the words of Mr. Benjamin Kidd who reminds us that forty per cent. of all the agricultural products which enter England come from the Tropics, and of these products the Transvaal may well claim her rightful share.

Passing now to the third part of our paper, namely, live stock, it may be said that, great as are the potentialities of our colony in the matter of farm crops and fruits, they are small in comparison to the magnitude of the live-stock industry. The enormous capital sunk in live stock in other lands will be better realised when we quote $\mathrm{Mr}$. Walter Heape, an English authority, who states that in Great Britain alone the vast sum of $\mathfrak{E} 450,000,000$ is invested in this industry. In the pre-war days and before the ravages of rinderpest great herds and vaster flocks roamed over the fertile untilled plains of the Free State and the Transvaal; and the countless herds of wild game attested the succulence of the natural grasses of the veld. But there is no doubt that soon these numbers will be surpassed by a more intensive husbandry and by better methods of feeding and farm management. Even now the people of the Transvaal are beginning to demand better beef, and for this purpose we may expect to see a large increase in Shorthorns, Herefords, Aberdeen Angus and Devons; while for dairy purposes Frieslands, Ayrshires, and the dainty Jersey will be found around our urban centres. Nor must we forget the most useful of all breeds in South Africa-the hardy Africander-the favourite foundation stock for breeding and patient, toilsome trekking.

It is difficult to form a reasonable estimate of the carrying capacity of the Transvaal for beef animals; but if we take-for the sake of illustration-the district of Waterberg, having an area of 15,503 square miles, and regard one-fifth of this as suitable for grazing, at ten acres to each beast we arrive at the carrying capacity of 198,400 animals, of a probable value of more than two million sterling. And if we are 
interested in the possibilities of the dairy industry, let us take 5000 dairy farmers, as a conservative estimate, for the whole of this colony. Give to each farmer 30 cows. Reckon to each cow $150 \mathrm{lbs}$. of butter per annum, and you will have produced each year in the Transvaal alone from these 150,000 cows $22,500,000 \mathrm{lbs}$. of butter. Sell this at $1 \mathrm{~s}$. per lb. (a low figure), and you will realise the grand total of $£ 1,125,000$ per year.

When we speak of sheep it is well to remember that the magnificent wool industry of Australia can be traced back to the year 1797, when Captain Macarthur purchased at the Cape of Good Hope three rams and five ewes of the purest Spanish Merino breed, which had been presented by the King of Spain to the Dutch Government. Now what has been the result? In the year 1792 we find that there were 105 sheep in the whole of Australia; and in 1906 in one State alone--New South Wales-there were $44,132,421$. And, what is more wonderful, in that State to-day there is not a single case of scab. It cannot be too strongly urged that until we eradicate scab from our flocks we shall never be able to speak with pride concerning our sheep industry. It does no good to point out that the Cape and the Orange River Colony have more scab than there is in the Transvaal. I have before me the latest figures: and I find that 852 farms are under quarantine for scab in the Transvaal alone. This number cannot be more than a small percentage of the actual number of cases. What does this mean to our industry? Let us take the quantity of wool exported from South Africa last year, which was $97,771,717 \mathrm{lbs}$; and remember that a rise of $1 \mathrm{~d}$. in the $1 \mathrm{~b}$. on this amount would mean the addition of $£ 407,380$ per annum to the wealth of our people. The potentialities of this industry are vast indeed, and most encouraging-more particularly when we receive reports to the effect that our greasy combing wools produce a "fabric of the finest texture" and are "freer from burr than the Australian."

Then glance over those famous sheep districts: Ermelo and Carolina, Standerton, Bethal, and Wakkerstroom, having a combined area of 10,224 square miles or $6,543,360$ acres. Reckon one sheep to every five acres with additional feed and we get a total of 1,308,672 sheep as the carrying capacity of our High Veld districts. It should, however, be clearly stated that the sheep-farmer of the future must make better provision for his flocks. Sheep-runs, valued at $£ 2$ per morgen ${ }^{1}$ lying idle for half the year during the time the farmers are away in the Low Veld, cannot be a profitable system of farming. And the experiments being made by such well-known sheep-farmers as the Messrs. A. and V. Robertson, of Wakkerstroom, in growing green winter feed for their flocks, should be watched by all growers. The rapid progress of the sheep industry is clearly shown by noting the difference in the wool exports for the last three years-in 1904, $£ 83,000$; in 1907, $£ 225,000$.

The subject of horse-breeding is one that must be approached with 
much caution, when we reflect upon the diseases which vex the equine tribe in the Transvaal. At the same time it may be said that there are certain districts in the Transvaal which are eminently suited to this branch of animal industry. Past experience has shown that there are few animals more hardy or more enduring than the South African bred horse-particularly for mounted infantry purposes. Although useful and hardy, the Colonial bred horse is lacking in size, and his conformation in some respects is slightly defective. There is therefore a need for the employment of a better class of stallion than is in common use in South Africa to-day; and with this end in view much good would result if a law were passed insisting on the castration of all inferior animals. This is now done in most progressive countries, notably in the State of Wisconsin in America, where-within a short period-over 100 unsound stallions have been rejected through the recent Act of the Legislature. A Horse Standardisation Commiltee of five members might be formed, comprising two farmers, the Principal Veterinary Surgeon, and the Government Veterinary Surgeon of the district, together with the Principal Veterinary Officer of the Army in South Africa. This Committee would forward to the Minister of Agriculture a list of all stallions which they considered fit for use, while the rest should be castrated and some small compensation given to the owners.

In conclusion it may rightly be urged that the figures set forth in this paper are merely hypothetical. But the fault lies in the fact that the Transvaal has at present no Bureau of Statistics. Any attempt therefore to forecast the future of our agricultural industry must remain more or less imperfect. It is, however, with pleasure that we recall the speech of the Right Hon, the Minister of Agriculture-General Botha-at the recent Agricultural Show at Potchefstroom, in which he spoke of his determination to forthwith establish a Division of Statistics in connection with the Department of Agriculture. The need of such data must be apparent to all. Go into any citrus orchard in the Transvaal, ask the farmer in charge what is the average number of oranges per tree, and note his utter lack of definite knowledge. Perhaps one tree has been counted; but of what use is that? It is sincerely to be hoped that the Government will make the rendering of agricultural statistics a compulsory measure. If the people are compelled to give the number and ages of each individual of their family, I see no reason why they should not do the same with regard to their flocks and herds.

In his admirable monograph on "The Breeding Industry" Mr. Walter Heape, already quoted, makes the following remark on the system of collecting live-stock statistics in England:-

"The only authority to which we can turn for figures is the Board of Agriculture, and there seems to be no doubt that the figures issued by the Board are very incomplete. From evidence I have obtained from various owners of live stock, it would appear that a considerable proportion of them make no returns at all to the Board of Agriculture."

It is hardly necessary to emphasise the unreliable nature of such statistical records. But we hope the Transvaal farmer will not follow the practice of his English brother, but will boldly strive to emulate his

vol. $\mathrm{XXV}$. 
fellow-citizen-the miner-whose accurate records show the whole world the ever-growing wealth of his splendid industry, and, at the same time, tell him how and where he can reduce his working costs.

In this brief paper no attempt has been made to discuss the work of the Transvaal Agricultural Department in relation to the agricultural industry of our colony. But the following note may be of interest as indicating the wide scope and varied activity of the Department:-

The Department of Agriculture was established by resolution of the Executive Council, passed August 20, 1902, the resolution being based upon a scheme prepared by the Agricultural Adviser, Mr. F. B. Smith, in accordance with instructions received from His Excellency the Governor, Viscount Milner.

The Department, which is intended to serve as the centre of the agricultural interests of the country, has been constituted very much on the lines of those existing in the United States of America and Canada and of the Agricultural Branch of the more recently formed Department of Agriculture and Technical Instruction in Ireland. The Department issues a quarterly periodical, The Transvaal Agricultural Journal, also Farmers' Bulletins, and an Annual Report. The Department consists of the following divisions:-

(1) Administrative; (2) Veterinary Science; (a) Bacteriology, (b) Contagious Diseases; (3) Chemistry; (4) Botany; (a) Agrostology and Economic Botany, (b) Co-operative Experiments, (c) Plant Pathology, (d) Experiment Station, Pretoria; (5) Entomology; (6) Forestry: Forest Stations-Irene, Pan, Belfast, Potchefstroom, Ermelo, Jessievale, Lichtenburg, Barberton, Graskop (Pilgrim's Rest), Woodbush; (7) Editorial; (8) Horticulture : Experiment Stations_-Warm Baths, Ermelo, Potchefstroom, and Zeerust; (9) Poultry; (10) Tobacco: Experiment Stations-Rustenburg and Barberton; (11) Co-operation; (12) Dairying; (13) Goverument Stud Farm, Standerton; (14) Government Experimental Farm, Potchefstroom; (15) Government Stud Sheep Farm, Ermelo; (16) Government Experimental Farm, Tzaneen; (17) Fencing; (18) Translator; (19) Registrar of Brands.

\section{THE GEOGRAPHY OF THE HIMALAYA MOUNTAINS AND TIBET. ${ }^{1}$}

TIE first three parts of this publication, which contain a summary of all that is at present known in regard to the geography of the regions with which they deal, are respectively entitled The High Peaks of. Asia, The Principal Mountain Ranges of Asia, and The Rivers of the Himalaya and

1 A Sketch of the Geography and Geology of the II Inalaya Mountains and Tibet. By Colonel S. G. Burrard, R.E., F.R.S., Superintendent, Trigonometrical Surveys, and H. H. Fayden, B.A., F.G.S., Superintendent, Geological Survey of India. Published by the order of the Government of India. Calcutta : Superintendent, Government Printing, India, 1907. Parts I., II., III. Price 2 rupees each part. Cf. also Mountain Panoramas from the Pamirs and $\mathbb{R}$ wan Lun, photographed and annotated by M. Aurel Stein. London: Royal Geographical Society. Ed. Stanford, 1908. 